\title{
Regional Bond as a Regional Development Resource (Case Study on the Bali Government)
}

\author{
Togar Situmorang \\ Doctoral Program in Law Faculty of Law, Udayana University, Denpasar, Bali
}

\begin{abstract}
The Province of Bali is a tourist area that is well known throughout the world, so that the issuance of regional bonds in the Province of Bali to develop the development of the tourism sector is the right step. Philosophically, the purpose of development carried out by the region has one goal, namely to create a prosperous life in accordance with the values of Pancasila. The emergence of bonds that refer to creative and constructive bonds that can provide added value and become a stimulus for regional economic development efforts through policies and further studies. The purpose of this study is to: (a) examine the nature of regional bonds in regional development (b) examine the regulation of the issuance of regional bonds as a resource for regional development in Bali. This research method uses normative legal law research type. The results of this study indicate that the Demand Side of Bali's Economic Construction in the first quarter of 2020 from the demand side stems from negative growth in the performance of foreign exports, investment and government consumption. Meanwhile, private consumption needs, the consumption component in the reporting period grew $2.25 \%$ (yoy), lower than the previous quarter's $6.58 \%$ (yoy), stemming from contraction in government consumption and slowing household consumption. In addition, the consumption performance of LNPRT also contracted during the quarter under review. The performance of private consumption, namely household consumption and LNPRT consumption, was restrained during the quarter under review. Household consumption grew by $2.90 \%$ (yoy) in the first quarter of 2020, lower than $5.70 \%$ (yoy) in the previous quarter. Meanwhile, the consumption performance of LNPRT decreased from $6.00 \%$ (yoy) to $-4.67 \%$ (yoy). On the other hand, the slowdown in household consumption performance in the quarter under review was caused by restrained purchasing power in line with the decline in tourism performance in the midst of the COVID-19 pandemic.
\end{abstract}

Keywords: Regional Bonds, Development Resources, Bali Province

DOI: $10.7176 / \mathrm{JLPG} / 117-05$

Publication date: January $31^{\text {st }} 2022$

\section{Introduction}

The province of Bali is a tourist area that is well known throughout the world, so the issuance of regional bonds for the Province of Bali to develop the development of the tourism sector is the right step. Philosophically, the purpose of development carried out by the region has one goal, namely to create a prosperous life in accordance with the values of Pancasila. However, as a legal state, the issuance of regional bonds certainly cannot be separated from regulations and there is also a need for certainty that protects the parties.

To avoid risks for the regions as debtors and investors as creditors, clear and definite legal instruments are needed. In fact, for the region the loss has been anticipated with strict procedures in the issuance of bonds. At the national level, the nominal amount of regional debt through the issuance of bonds has been limited and based on the amount of the previous RAPBD. In addition, bond funds must be used for development programs that provide benefits to the region, not development programs that do not have investment value.

The problem with the Bali Province in issuing regional bonds as an alternative source of financing for regional development is that there are several obstacles related to the philosophical problem, namely the absence of justice based on the fifth principle of Pancasila and regulations from the Central Government regarding the procedures for assessing, calculating and considering the issuance of regional bonds. considering letter $b$ regarding the phrase other resources in the Law of the Republic of Indonesia Number 33 of 2004 concerning the Financial Balance between the Central Government and the Regional Government where the Province of Bali in generating income through the tourism industry is sourced and based on Balinese Culture. Related to that, there are also juridical problems in the Bali Province in issuing regional bonds, namely the incompatibility of the Central Government regulations regarding the authority to issue and approve the issuance of regional bonds which are regulated between the Financial Services Authority Regulations and the Minister of Finance Regulations as well as the many overlapping rules due to management audits. local government finances in the Revenue and Expenditure Budget of region is entirely under the responsibility of the Supreme Audit Agency (BPK), while for the management of a regional bond, is it permissible for the Supreme Audit Agency (BPK) to participate in managing it because of its nature as an examiner. ${ }^{1}$ It can be stated further that the sociological problem lies in the lack of readiness of local governments and human resources in issuing and managing regional

${ }^{1}$ Abdul Manan, 2012, The Role of Law in Economic Development, Kencana Prenada Group, Jakarta.page. 45 
bonds which are vulnerable to a game between project value (regional infrastructure financing) and the value of regional bonds offered with the possibility of a budget mark-up level occurring.

\subsection{Legal Issues}

1. What is the nature of regional bonds in regional development in the province of Bali?

How are Regional Bonds Issuing Regulations as a Regional Development Resource for Bali

\subsection{Research Methods}

This research method uses normative legal research type. The approaches used include statutory approaches, conceptual approaches and analytical approaches. The material for this research uses legal materials, namely primary, secondary and tertiary legal materials, which are collected using document study techniques which are then identified and classified and then analyzed qualitatively. ${ }^{1}$

\subsection{Results and Discussion}

\subsubsection{The nature of bonds as a source of financing for regional development in Bali}

The budget is a policy instrument owned by the Government to describe a comprehensive statement of state priorities. Budget can also be interpreted as government policy in the financial sector which is a guideline in making budget allocation policies and financing State tasks. Budget is generally defined as a financial calculation that describes the activities of an organization based on the calculation of expenditures supported by the calculation of income that has been planned previously. Technically a budget is a document consisting of words and numbers. ${ }^{2}$ The elements contained in the state budget are essential things that aim to prosper the people. Budgeting is carried out through top-down and bottom-up development planning mechanisms. The annual operational planning contained in the state revenue and expenditure budget (APBD) is an elaboration of the policy points set out in the regional development plan document. The budgeting stage is very important, because an ineffective and not performance-oriented budget will be able to thwart the plans that have been prepared. So the purpose of budgeting must be understood by policy formulation. ${ }^{3}$

The government in implementing broad regional autonomy requires sufficient funds and continues to increase in accordance with the increasing demands of society, government activities and development. These funds are obtained from the ability to explore their own financial sources supported by the balance of central and regional finance as a source of financing. Regional finance is a benchmark for determining capacity in carrying out autonomy tasks, in addition to other benchmarks such as natural resource capabilities, demographic conditions, regional potential, and community participation. Therefore, the government in regulating regional financial budgets must have a plan in carrying out regional development.

Whereas in the implementation of regional autonomy, Regional Governments have the right and obligation to regulate and manage their government affairs, but encounter limitations in funding sources. Most districts and cities rely heavily on balancing funds provided by the Central Government, be it Revenue Sharing Funds, DAU and DAK. Another source of income comes from Regional Original Income which is also limited. This is because the three sources of funding are mostly absorbed in routine expenditures. With these financial conditions, it is certainly difficult for local governments to carry out various development projects due to budget constraints. Therefore, various breakthroughs must be made by the regional government in an effort to find sources of development financing in order to achieve the successful implementation of regional autonomy. The existence of Law Number 33 of 2004 which replaced Law Number 25 of 1999 concerning Financial Balance between the Central Government and Regional Governments provides an opportunity for regional governments to raise funds (Fund Raising) in the context of regional development and development through the issuance of regional bonds such as as set forth in Article 57 of the Law, which in more detail regulates regional bonds as a source of regional financing. Regional bonds as a source of funds have long been used as a discourse and discussion material, both in formal forums both at the regional and central levels. ${ }^{4}$

Regional bonds are an alternative to obtain additional sources of finance for the regions. Until now, not many regions have issued regional bonds, because regional bonds have not been fully understood and it seems that it will become a burden for the regions. So that to issue bonds, regional bonds are taken based on careful consideration from both regional heads, Regional People's Representative Assembly and also the central government. $^{5}$

\footnotetext{
${ }^{1}$ Peter Mahmud Marzuki, 2009, Legal Research, Kencana, Jakarta. P. 69

${ }^{2}$ Gemkow, T., \& Zürn, M. (2012). Constraining International Authority through the Rule of Law: Legitimatory Potential and Political Dynamics. Rule of Law Dynamics: In an Era of International and Transnational Governance.pg. 67

${ }^{3}$ Ateng Syafrudin, 2010, Towards a Clean and Responsible State Administration, Pro Justisia Journal, Edition IV, Parahyangan University, Bandung.pg. 89

${ }^{4}$ Gunawan Setiardja A., 2010, Legal and Moral Dialectic in Indonesian Community Development, Kanisius, Jogjakarta. Pg.105

${ }^{5}$ Ibrahim, 2003, Constitutional Oversight System Between Legislative and Executive Powers in Renewing the 1945 Constitution, Unpad Postgraduate Program, Bandung.pg.56
} 
The increase in regional revenues from the issuance of regional bonds will support the development of the public sector in the regions according to the allocation of funds originating from regional bond funds. The local government is required to pay the debt and interest and must be included in the RAPBD every year. Thus, regional bonds need to be carried out carefully and carefully because bond funds are debt not loans and the repayment of the debt is disserted with interest. At first glance, bonds are a burden for the regions, but in fact the proceeds from the issuance of bonds are very beneficial for the regions, especially for regions that need bailout funds to carry out development.

Thus, the implications of developing regional autonomy are not merely an addition to the affairs delegated, but also how much authority is delegated to provide the ability to take initiatives in regional financial management so that regions can reduce their degree of dependence on the center and can finance regional development activities.

Based on Article 1 point 7 of Law Number 17 of 2003 concerning State Finances that regional finances are all regional rights and obligations in the context of administering regional government which can be valued in money, including all forms of wealth related to the rights and obligations of the region. The financial factor is an important factor in measuring the level of regional capability in implementing its autonomy. Regional financial conditions determine the form and variety of activities to be carried out by local governments.

Regional finances can simply be formulated as all rights and obligations that can be valued in money, as well as everything in the form of money or goods that can be used as regional assets as long as they are not owned/controlled by the state or higher regions and other parties in accordance with applicable laws and regulations. From the definition above, it can be seen that in regional finance there are two important elements, namely: ${ }^{1}$

1. All rights are intended as the right to collect regional taxes, regional levies and/or revenues and other sources

in accordance with applicable regulations constitute regional revenues so as to increase regional wealth;

2. Regional obligations may be in the form of an obligation to pay or in connection with a bill to the region in the

context of financing the regional household as well as the implementation of general tasks and development tasks by the region concerned.

One of the problems in the implementation of regional autonomy is regarding the financial capacity of the regions because it involves the financing of the administration of government affairs and the implementation of development in an effort to improve the welfare of the government. ${ }^{2}$ The problem of regional capacity means how the region can obtain and increase sources of regional income to carry out its government activities. In carrying out government, development and community activities, sources of funds are needed to finance these government expenditures.

\subsubsection{Regulation of Issuance of Regional Bonds as a Resource for Regional Development of Bali}

Bali's Economic Construction on the Demand Side in the first quarter of 2020 on the demand side stemmed from negative growth in the performance of foreign exports, investment and government consumption. ${ }^{3}$ Meanwhile, household consumption performance was still able to show positive growth although it was slower than the previous period. Meanwhile, private consumption needs, the consumption component in the reporting period grew $2.25 \%$ (yoy), lower than the previous quarter's $6.58 \%$ (yoy), stemming from contraction in government consumption and slowing household consumption. In addition, the consumption performance of LNPRT also contracted during the quarter under review. The performance of private consumption, namely household consumption and LNPRT consumption, was restrained during the quarter under review. Household consumption grew by $2.90 \%$ (yoy) in the first quarter of 2020 , lower than $5.70 \%$ (yoy) in the previous quarter. Meanwhile, the consumption performance of LNPRT fell from $6.00 \%$ (yoy) to $-4.67 \%$ (yoy). On the other hand, the slowdown in household consumption performance in the quarter under review was caused by restrained purchasing power in line with the decline in tourism performance in the midst of the COVID-19 pandemic. $^{4}$

Regional bonds are debt securities issued by regional governments that are offered to the public through public offerings on the capital market. These bonds are not guaranteed by the Central Government (Government) so that all risks that arise as a result of the issuance of Regional Bonds are the responsibility of the Regional Government. $^{5}$

The loan will be repaid according to the agreed terms and conditions. Regional governments that issue regional bonds are obliged to pay interest periodically in accordance with a predetermined period of time. At maturity, the local government is obliged to repay the principal of the loan. The purpose of the issuance of

\footnotetext{
${ }^{1}$ Budi S. Purmono, 2006, Regional Bonds as an Alternative for Financing Regional Development in Indonesia, Proceedings of Kopertis Region IV, Vol. 2 No.1.

${ }^{2}$ Irham Fahmi, 2013, Shares and Bonds Secret, Alfabeta, Yogyakarta, p.90

${ }^{3}$ Ujang Bahar, 2009, Regional Autonomy Against Foreign Loans Between Theory and Practice, PT Index, Jakarta. Case. 89

${ }^{4}$ Setiadi, W. (2016). Study of Regional Bonds as an Alternative Source of Financing for Regional Development (Case Study in Central Java Provincial Government). Journal of RAK (Financial Accounting Research), 1(1), 61-74.

${ }^{5}$ Dewi Okta and David Kaluge, Analysis of Opportunities for Issuing Regional Bonds as an Alternative to Regional Financing, Journal Of Indonesia Applied Economics, Vol. 5 No. 2
} 
Regional Bonds is to finance a public sector investment activity that generates revenue and provides benefits to the community. For this reason, it should be noted that the issuance of bonds is not intended to cover regional cash shortages. Regional Bonds will be traded on the domestic capital market in accordance with the capital market laws and regulations.

\subsection{Conclusion}

Based on the discussion above, it can be concluded as follows:

1. Regional bonds are debt securities issued by regional governments that are offered to the public through public offerings on the capital market. These bonds are not guaranteed by the Central Government (Government) so that all risks that arise as a result of the issuance of Regional Bonds are the responsibility of the Regional Government. Issuance of debt securities is evidence that the local government has made a loan/debt to the holder of the debt securities. The loan will be repaid according to the agreed terms and conditions. Regional governments that issue regional bonds are obliged to pay interest periodically in accordance with a predetermined period of time. At maturity, the local government is obliged to repay the principal of the loan. The purpose of the issuance of Regional Bonds is to finance a public sector investment activity that generates revenue and provides benefits to the community. The province of Bali as one of the national cultural centers and trade centers for international tourism services has the urgency of developing facilities and infrastructure, so that costs are needed from various sources that have been included in the source of regional income.

2. Regional bonds are debt securities issued by regional governments that are offered to the public through public offerings on the capital market. These bonds are not guaranteed by the Central Government (Government) so that all risks that arise as a result of the issuance of Regional Bonds are the responsibility of the Regional Government. Regional governments that issue regional bonds are obliged to pay interest periodically in accordance with a predetermined period of time. At maturity, the local government is obliged to repay the principal of the loan. The purpose of the issuance of Regional Bonds is to finance a public sector investment activity that generates revenue and provides benefits to the community. For this reason, it should be noted that the issuance of bonds is not intended to cover regional cash shortages. Regional Bonds will be traded on the domestic capital market in accordance with the capital market laws and regulations.

\section{Reference}

Abdul Manan, 2012, The Role of Law in Economic Development, Kencana Prenada Group, Jakarta.

Altman, E. I. (2013). Predicting financial distress of companies: revisiting the Z-score and ZETA® models. In Handbook of research methods and applications in empirical finance. Edward Elgar Publishing.

Ateng Syafrudin, 2010, Towards a Clean and Responsible State Administration, Pro Justisia Journal, Edition IV, Parahyangan University, Bandung.

Budi S. Purmono, 2006, Regional Bonds as an Alternative for Financing Regional Development in Indonesia, Proceedings of Kopertis Region IV, Vol. 2 No. 4.

Damon, W., and Colby, A, 2015, The power of ideals: The real story of moral choice. Oxford University Press, USA.

Halim Abdul and Muhammad Iqbal, 2012, Regional Financial Management, UPP AMP YKPN, Yogyakarta.

Gemkow, T., \& Zürn, M. (2012). Constraining International Authority through the Rule of Law: Legitimatory Potential and Political Dynamics. Rule of Law Dynamics: In an Era of International and Transnational Governance.

Gunawan Setiardja A., 2010, Legal and Moral Dialectic in Indonesian Community Development, Kanisius, Jogjakarta.

Hadi, A. (2014). Study Analysis of the Legality of Shari'a Regional Regulations in the Perspective of the Hierarchical Theory of Legal Norms. Journal of Ummul Qura, 4(2).

Hadin Mudjad, and Nunuk Nuswardani, 2012, Research on Contemporary Indonesian Law, Genta Publishing, Yogyakarta.

Hans Kelsen, 2006, General Theory of Law \& State, Transaction Publishers, New Brunswik.

Hector Hawton, 1958, Philosohy for Pleasure: An Adventure In Ideas, IMF, Gramedia Pustaka Utama, Jakarta.

Hendry Maddick, 2004, Democracy, Decentralization and Development. Translated freely with the title Decentralization in Practice, Printing I, Pustaka Kendi, Yogyakarta.

Hodgson, L. P. (2012). Realizing external freedom: The Kantian argument for a world state. Kant's political theory: Interpretations and applications.

Ibrahim, 2003, Constitutional Oversight System Between Legislative and Executive Powers in Renewing the 1945 Constitution, Unpad Postgraduate Program, Bandung. 